\title{
Fenilketonürili Çocukların Beslenme Durum ve Davranışları Üzerine Annelerin Besleme Davranışlarının Etkisi
}

\section{The Effect of Maternal Feeding Behaviours on Eating Attitudes and Behaviours of Children with Phenylketonuria}

\author{
Şule AKTAÇ, Gül AKDUMAN, Simay KUNDAKÇI, Dicle KARĞIN, Hayrunisa IÇEN
}

Marmara Üniversitesi, Sağlık Bilimleri Fakültesi, Beslenme ve Diyetetik Bölümü, İstanbul, Türkiye

\section{ÖZ}

Amaç: Çalışmanın amacı annelerin besleme davranışlarının, Fenilketonüri (PKU)'li çocukların beslenme durumları ve davranışlarına etkisini saptamaktır.

Gereç ve Yöntemler: PKU Aile Derneği'ne üye 2-11 yaș aralığındaki PKU'lu çocuklar ve annelerine, yüz yüze görüşme metodu kullanılarak, ailenin sosyodemografik özelliklerini ve annenin çocuğu besleme davranışlarını belirlemeye yönelik anket formu uygulanmış, çocukların antropometrik ölçümleri alınmıştır. Geriye dönük bir günlük besin tüketim kayıtları alınarak, beslenme bilgi sistemi bilgisayar programı ile günlük alınan enerji, makro ve mikro besin ögeleri hesaplanmış ve günlük gereksinimleri karşılama düzeyleri belirlenmiştir. Çocukların antropometrik değerlendirmesi WHO AnthroPlus Programı ile yapılmış, yaşa göre ağırlık z-skoru (WAZ), yaş göre boy z-skoru (HAZ) ve yaş göre BKI z-skoru (BAZ) değerleri hesaplanmıştır.

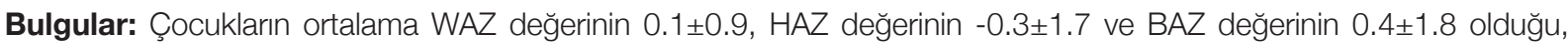
annenin besleme davranışının çocuğun antropometrik ölçülerini etkilediği tespit edilmiştir (p<0.05). Çocukların enerji gereksinimleri \%77.7 oranında karşılanırken, protein, B6, B12 ve C vitamini alımlarının önerilerin üzerinde, folat alımının ise önerilerin altında olduğu saptanmıştır. Annenin çocuğun beslenmeyi reddettiğinde gösterdiği besleme davranışının, çocuğun makro ve mikro besin ögesi alımları ile kan fenilalanin düzeyini etkilemediği bulunmuştur (p>0.05). Çocukların büyük çoğunluğunun (\%86.7) diyetine uyumlu olduğu, diyetine uyumlu çocukların annelerinin yașlarının ise daha yüksek olduğu saptanmıştır ( $p=0.03$ ). Besin alımını reddeden çocukların annelerinin sıklıkla çocuğu beslemekten vazgeçmediği (\%80.0), bir süre bekledikten sonra tekrar beslediği (\%26.7) ve oyun haline dönüştürerek beslediği (\%23.3) belirlenmiştir.

Sonuç: Annelerin besleme davranışları çocukların beslenme durumunu etkilemektedir. PKU'lu çocukların yaşam boyu uyguladıkları diyet tedavisine uyumu arttırmak için ebeveynlere destekleyici beslenme eğitimleri planlanarak, tedavinin bir parçası haline getirilmesi sağlanmalıdır.

Anahtar Sözcükler: Anne davranışı, Beslenme davranışı, Beslenme durumu, Fenilketonüri, Metabolik bozukluklar

(1)

AKTAÇ Ş : :0000-0002-2158-5015 ÖĞREN G : 0000-0001-5702-9478 FERELIS : :0000-0002-7962-2624 KARĞIN D : :0000-0002-7393-730X IÇEN H : 0000-0001-8083-8214

\begin{abstract}
Çıkar Çatışması / Conflict of Interest: Tüm yazarlar adına, sorumlu yazar çıkar çatışması olmadığııı belirtir.
Etik Kurul Onayı / Ethics Committee Approval: Bu çalıșmada ulusal ve uluslararası etik kurallara uyulmuştur. Çalışmanın yapılabilmesi için Marmara Üniversites Sağllık Bilimleri Enstitüsü'nden etik kurul izni (28.03.2016-16) ve PKU Aile Derneği'nden gerekli izinler ile birlikte çalışmaya katılan çocuk ve ebeveynlerin onamları alınmıştır.

Yazarların katkısı / Contribution of the Authors: AKTAC Ș:Araștırmanın hipotezini ve fikrini olușturmak, tasarlamak, araștırmanın yürütülmesini organize etmek, katıımcıların takibi, verilerin toplanması, verilerin düzenlenmesi ve raporlanması, yorumlanması, kaynak taranması ve makalenin yazımı için sorumluluk almış ve katk sağlamıştı. ÖĞREN G: Araștırmanın hipotezini ve fikrini olușturmak, tasarlamak, katıımcıların takibi, verilerin toplanması, verilerin düzenlenmesi ve raporlanmas ve yorumlanması, kaynak taranması ve makalenin yazılmasında katkı sağlamıștı. FERELi S: Araştırmanın hipotezini ve fikrini oluşturmak, tasarlamak, katıımcıların takibi, verilerin toplanması, verilerin düzenlenmesi ve raporlanması ve yorumlanması, kaynak taranması ve makalenin yazılmasında katkı sağlamıștır. KARĞıN $\boldsymbol{D}$ Araștırmanın hipotezini ve fikrini olușturmak, tasarlamak, katılımcıların takibi, verilerin toplanması, verilerin düzenlenmesi ve raporlanması ve yorumlanması, kaynak taranması ve makalenin yazılmasında katkı sağlamıștır. IÇEN H: Araștırmanın hipotezini ve fikrini olușturmak, tasarlamak, katılımcıların takibi, verilerin toplanması, verilerin düzenlenmesi ve raporlanması ve yorumlanması, kaynak taranması ve makalenin yazılmasında katkı sağlamışıır.

Atıf yazım şekli / How to cite : Aktaç Ş, Öğren G, Fereli S, Karğın D, İçen H. Fenilketonürili Çocukların Yeme Tutum Ve Davranışları Üzerine Annelerin Besleme Davranışlarının Etkisi. Türkiye Çocuk Hast Derg 2021;15:174-180.
\end{abstract}

Teşekkür: Bu araştırmanın yapılabilmesi için destek olan PKU Aile Derneği'ne ve çalışmaya katılan anne ve çocuklarına teşekkür ederiz.
Yazıșma Adresi / Correspondence Address:

Şule AKTAÇ

Marmara Üniversitesi, Sağlık Bilimleri Fakültesi,

Beslenme ve Diyetetik Bölümü, İstanbul, Türkiye

E-posta: suleaktac@hotmail.com
Geliş tarihi / Received : 10.05.2019 Kabul tarihi / Accepted : 07.05.2020 Elektronik yayın tarihi $\quad$ : 29.09.2020 Online published

DOI: 10.12956/tchd.561368 


\section{ABSTRACT}

Objective: The aim of this study was to determine the effect of maternal feeding behavior on nutrition status and behaviors of children with phenylketonuria (PKU).

Material and Methods: The PKU Family Association's 2-11 year-old children and their mothers were administered face to face questionnaire to determine the sociodemographic characteristics of the family, mothers' feeding attitudes of their children and anthropometric measurements of the children. One-day food consumption records were taken retrospectively, daily energy, macro and micro nutrients were calculated by the Nutrition Information System computer program and the level of meeting daily requirements was determined. Children's anthropometric evaluation was done with WHO AnthroPlus Program, weight for age z-score (WAZ), height for age z-score (HAZ) and BMl for age z-score (BAZ) were calculated.

Results: It was found that the mean WAZ value of the children was $0.1 \pm 0.9$, the HAZ value was $-0.3 \pm 1.7$ and the BAZ value was 0.4 \pm 1.8 and the feeding behavior of the mother affected the anthropometric measures of the child $(p<0.05)$. While energy requirements were met by $77.7 \%$, protein, vitamin B6, B12 and C intake was above the recommendations and folate intake was below the recommendations. It was detected that the feeding behavior of the mother when child refused food intake, did not affect the child's blood phenylalanine level and macro-micro nutrient intake ( $p>0.05)$. The majority of the children (86.7\%) were found to be compatible with their diet and their mothers were found to higher age $(p=0.03)$. It was determined that the majority of mothers $(80.0 \%)$ did not give up when they refused to feed and that feeding (26.7\%) after feeding them for a while and trying to feed them into games (23.3\%).

Conclusion: Feeding attitudes of mothers affect the nutritional status of children. In order to increase compliance with the lifelong dietary treatment of children with PKU, supportive nutrition education for parents should be planned and provided part of the treatment.

Key Words: Maternal behavior, Nutritional status, Eating behavior, Phenylketonuria, Metabolic disorders

\section{GiRiş}

Metabolizma hastallklarında; karbonhidrat, yağ ve protein sentez ya da katabolizmasındaki metabolik yollarda enzim eksikliğine bağlı toksik etki gösterebilecek metabolitler birikmekte ya da son ürün üretilememektedir. Bu hastalıklar genellikle otozomal resesif olarak taşınmaktadır. Türkiye İstatistik Kurumu Aile Yapısı Araştırma Raporu 2006 verilerine göre Türkiye'de akrabasılyla evli olan 18 yaş ve üzeri bireylerin oranı \%20.9'dur (1). Ülkemizde akraba evliliğinin yüksek olması kalıtsal hastalıkların görülme sıkığını da artırmaktadır $(2,3)$. Dünyada en sık görülen amino asit metabolizma bozukluğu olan fenilketonüri, fenilalanin hidroksilaz (PAH) enziminin yetersizliğine bağı gelişen kalıtsal metabolik bir bozukluktur (4-6). Fenilalanin hidroksilaz, fenilalanini tirozine çeviren, kofaktörü tetrahydrobiopterin $\left(\mathrm{BH}_{4}\right)$ olan karaciğerde üretilen bir enzimdir. Fenilalanin hidroksilaz yetersizliğinde kanda fenilalanin düzeyleri yükselir ve yüksek düzeydeki fenilalanin beyinde toksik etki göstermektedir (5). Türkiye Halk Sağlığı Kurumu verilerine göre Türkiye'de PKU görülme sıklığı 1/6228'dir. Fenilalanin hidroksilaz enzim yetersizliği ise her 2600 canlı doğumda 1'dir. Avrupa ülkelerinde bu oran 1/10000 canlı doğum olup, diğer ülkelerle karşılaştırıldığında Türkiye oldukça yüksek bir insidansa sahiptir $(7,8)$.

Doğumsal metabolik hastalıklarda diyet tedavisi, toksititeye sebep olan ögenin diyetten çıkarılması veya miktarının azaltılması ile merkezi sinir sistemi korunmakta, normal büyüme ve gelişme sağlanmakta, biyokimyasal parametreler düzenlenmekte ve diyet tedavisiyle yeterli enerji, protein, vitamin ve mineral alımı sağlanmaktadır (9). Bu nedenle mümkün olan en kısa sürede diyet tedavisine başlanmalı ve diyet tedavisine ömür boyu devam edilmelidir. Fenilketonürili çocukların aileleri yaşam boyu çocuğun diyetini düzenleyerek tedavilerinde etkin rol oynamaktadır. Bu süreçte ebeveynlerin tutum ve davranışı kadar çevrenin tutum ve davranışı da çocuğun diyetine uyumunda önem arz etmektedir. Bu durum doğrudan çocuğun büyüme ve gelişmesini etkilemektedir (10). Fenilketonüri hastaları yüksek miktarda fenilalanin içeren et, süt ve süt ürünleri, yumurta, balık ve tavuk gibi protein kaynaklarını, yağlı tohumları, normal ekmek ve unları, kuru baklagilleri ve aspartam içeren besinleri tüketmemektedir. Fenilalanin intiyaçları sebze ve meyve gibi düşük miktarda protein içeren besinlerden karşılanmakta, ancak bu besinlerin de alım miktarları kısıtlanmaktadır (11). Büyüme ve gelişme için gerekli günlük protein intiyacı ise fenilalanin içermeyen özel amino asit karışımlarından sağlanmaktadır (12). Ayrıca; protein ve fenilalanin içeriği düşük, enerji içeriği yüksek özel ürünlerden de destek alınmaktadır. Bu ürünler; düşük proteinli özel sütler, içecekler, makarna çeşitleri, pirinç, un, ekmek, çikolata, kurabiye, bisküvi ve yumurta ikamesi gibi besinlerdir (13). Fenilketonürili hastaların diyetlerinde nişasta, şeker ve yağlar önemli enerji kaynaklarıdır. Tüm bu etmenler çocukların diyetine uyumunu zorlaştırmakta ve besin reddetme yönünde davranışları da beraberinde getirmektedir. Protein destek ürünleri, amino asitler, gece beslenme uygulamaları çocukların beslenmelerinde zorluklara neden olabilmektedir. Kullanılan ürünlerin tatlarının beğenilmemesi, besin çeșitliliğinin yetersiz olması ve öğün sürelerinin çok uzun olması, yaşam boyu süren beslenme programına uyumda bıkkınlık, diyetinde olmayan yiyeceklere istekteartış gibi çeşitli nedenler çocuklarda beslenme sorunlarının temelini oluşturmaktadır (14). Ayrıca eşlik eden nörolojik ya da psikososyal sorunlar, kısıtı diyetten kaynakı besin ögesi yetersizlikleri ve özel besinlerin maliyetinin yüksek olması da diyet tedavisinin diğer zorluklarındandır (15). Bu kısıtı diyete uyma çabası hem aileler hem de çocuklarda belirgin bir stres yaratmaktadır (16). Fenilketonürili çocuklarda sınırlı beslenme düzeni, karşllaşılan yeni besine karşı olumsuz tutuma neden olmakta, besin kabulü ve tat tercihlerini etkilemektedir (17). 
Literatürde PKU'lu çocukların yeme tutum ve davranışlarına yönelik çalışmalar sınırıdır. Bu çalışmanın amacı; PKU'lu çocukların beslenme tutum ve davranışlarına annelerin besleme davranışlarının etkisini belirlemektir.

\section{GEREÇ ve YÖNTEMLER}

Kesitsel, tanımlayıcı tipteki bu çalışma İstanbul ilinde, PKU Aile Derneği'ne üye 30 aile ile Nisan - Mayıs 2016 tarihleri arasında yürütülmüştür. Çalışmanın evrenini PKU Aile Derneği'neüye, PKU hastalığına sahip, 2-11 yaş aralığında, oral alımı olan, gönüllü çocuklar ve anneleri oluşturmuştur. Çalışmanın yapılabilmesi için Marmara Üniversitesi Sağllk Bilimleri Enstitüsü’nden etik kurul izni (28.03.2016-16) ve PKU Aile Derneği'nden gerekli izinler ile birlikte çalsşmaya katılan çocuk ve ebeveynlerin onamları alınmıștır.

Aileye ve çocuğa ilişkin sosyodemografik özellikler, antropometrik özellikler, çocuğun beslenme programı ile beslenme tutum ve davranışlarını belirlemeye yönelik bilgiler bir anket aracilığılla edinilmiștir. Anket formu araștırmacılar tarafından çocuk ve anne ile yüz yüze görüşülerek uygulanmıştır. Çocuğun son kontrol sırasındaki kan fenilalanin düzey bilgisi takip dosyasından alınmıştır. Çocuğun diyetine uyumu anne beyanına dayanmaktadır.

Anneden geriye dönük olarak çocuğun 1 günlük besin tüketim kaydı alınmış, BeBiS $®$ Bilgisayar Programı ile günlük alınan enerji, makro ve mikro besin ögeleri hesaplanmıştır. Bu besin ögelerinin günlük gereksinimleri karşılama durumları Türkiye'ye Özgü Beslenme Rehberi kullanılarak belirlenmiştir (18).

Çocukların boy uzunlukları ve vücut ağırlıkları PKU Aile Derneği'nde standartlara uygun olarak ölçülmüş, beden kütle indeksi (BKI) "vücut ağırlığı (kg) / boy uzunluğu (m) ${ }^{2}$ formülü kullanılarak hesaplanmıştır. Antropometrik değerlendirme WHO AnthroPlus Programı ile "WHO 5-19 yaş grubu çocuklar için referans değerleri-2007" kullanılarak yapılmış, yaşa göre ağıllık z-skoru (WAZ), yaşa göre boy z-skoru (HAZ) ve yaşa göre BKi z-skoru (BAZ) değerleri hesaplanmıştır (19).

\section{İstatistiksel Analiz}

Çalışmanın veri analizi SPSS versiyon 15.0 İstatistik Programı ile yapılmıştır. Değişkenlerin normal dağılım gösterip göstermediği Kolmogrov-Simirnov Testi kullanılarak değerlendirilmiştir. Parametreler normal dağlıma uygunluk göstermediğinden Kikare, Mann-Whitney $U$ ve Kruskal Wallis testleri uygulanmıştır. Çalışmanın anlamlılık düzeyi $p<0.05$ olarak kabul edilmiştir.

\section{BULGULAR}

Çalışmaya katılan annelerin çoğu (\% 60.0) 30-39 yaş aralığında, \% 43.3'ü lise ve üzeri eğitim seviyesine sahip ve \%66.7'sinin ekonomik durumu gelirleri giderlerine eșittir. Annelerin ortalama
Tablo I: Çocuğa ilişkin antropometrik ölçümler.

\begin{tabular}{|l|c|c|c|}
\multicolumn{1}{c|}{$\begin{array}{c}\text { Antropometrik } \\
\text { Ölçümler }\end{array}$} & Ort \pm SS & $\begin{array}{c}\text { Alt } \\
\text { değer }\end{array}$ & $\begin{array}{c}\text { Üst } \\
\text { değer }\end{array}$ \\
\hline Vücut ağırlığı (kg) & $24.4 \pm 8.3$ & 11.0 & 45.0 \\
\hline Boy uzunluğu (cm) & $119.5 \pm 17.6$ & 83.0 & 155.0 \\
\hline BKI & $16.9 \pm 3.01$ & 7.9 & 24.0 \\
\hline WAZ & $0.1 \pm 0.9$ & -1.84 & 1.41 \\
\hline HAZ & $-0.3 \pm 1.7$ & -4.41 & 4.91 \\
\hline BAZ & $0.4 \pm 1.8$ & -6.95 & 2.85 \\
\hline
\end{tabular}

Tablo II: Çocukların diyetlerinin enerji ile bazı mikro ve makro besin ögelerini karşılama durumu.

\begin{tabular}{|l|c|c|c|}
\hline $\begin{array}{l}\text { Enerji ve besin } \\
\text { ögeleri }\end{array}$ & \multicolumn{3}{c}{ Karşılama yüzdesi } \\
\hline Enerji (kkal) & $77.7 \pm 34.1$ & 29.5 & 167.7 \\
\hline Protein (g) & $187.5 \pm 125.3$ & 23.0 & 519.2 \\
\hline B6 vitamini (mg) & $375.9 \pm 252.0$ & 63.3 & 978.3 \\
\hline B12 vitamini (mcg) & $136.0 \pm 51.9$ & 0.0 & 215.0 \\
\hline Folik asit (mcg) & $70.0 \pm 32.6$ & 31.0 & 169.2 \\
\hline C vitamini (mg) & $354.2 \pm 192.1$ & 71.1 & 825.8 \\
\hline Demir (mg) & $240.6 \pm 168.1$ & 28.8 & 609.0 \\
\hline Kalsiyum (mg) & $184.3 \pm 156.3$ & 12.1 & 558.7 \\
\hline
\end{tabular}

yaşının 34.6 $65.6 \mathrm{yll}$, çocukların ortalama yaşının ise $7.0 \pm 2.3$ yıl olduğu belirlenmiştir. Çocukların \% 40'ının ailenin birinci çocuğu, olduğu tespit edilmiştir. Çocukların kan fenilalanin düzeylerinin $6.6 \pm 3.1 \mathrm{mg} / \mathrm{dL}$ (Alt-üst değer= $3.0-14.9 \mathrm{mg} / \mathrm{dL}$ ) ve \%43.3'ünün kan fenilalanin düzeyinin normal değerlerin üzerinde olduğu belirlenmiștir.

Çocukların ortalama vücut ağıllı̆ının $24.4 \pm 8.3 \mathrm{~kg}$, boy uzunluğunun $119.5 \pm 17.6 \mathrm{~cm}$ olduğu bulunmuştur. Çocukların ortalama z-skoru değerleri incelendiğinde WAZ değerinin $0.1 \pm 0.9$, HAZ değerinin $-0.3 \pm 1.7$, BAZ değerinin $0.4 \pm 1.8$ olduğu görülmüştür. Çocukların ortalama z-skor değerlerinin normale yakın olduğu belirlenirken, HAZ değeri ortalamasının sıfırın altında olduğu tespit edilmiştir (Tablo I). Uygulanan diyet programlarının büyük çoğunluğu (\%96.7) diyetisyen tarafından oluşturulmuş olup, diyet takibinin \%70.0 oranında 6 ayda bir yapıldığı saptanmıştır.

Besin tüketim kayıtları değerlendirildiğinde günlük ortalama enerji alımı $1425.0 \pm 618.9 \mathrm{kkal}$, protein alımı $15.4 \pm 7.5 \mathrm{~g}$, yağ alımı $32.7 \pm 9.8 \mathrm{~g}$, karbonhidrat alımının ise $51.8 \pm 9.3 \mathrm{~g}$ olduğu tespit edilmişstir. $\mathrm{B}_{6}, \mathrm{~B}_{12}, \mathrm{C}$ vitamini ve folat alım ortalamalarının ise sirasiyla $2.4 \pm 1.5 \mathrm{mg}, 1.7 \pm 0.7 \mathrm{mcg}, 222.4 \pm 117.2 \mathrm{mg}$ ve $151.4 \pm 64.4$ mg olduğu saptanmıştır. Günlük ortalama kalsiyum alımının $1.6 \mathrm{~g}$ ve ortalama demir alımının $23.6 \pm 16.9$ mg olduğu bulunmuştur. Tablo Il'de çocukların günlük enerji ile bazı makro ve mikro besin ögesi alımlarının önerileri karşılama yüzdeleri verilmiştir. Enerji ve folat alımının önerilerin altında; protein, $B_{6}$, $B_{12}$ ve $C$ vitamini ile demir ve kalsiyum alımlarının önerilerin 
Tablo III: Çocukların diyete uyumu ile enerji ile bazı makro ve mikro besin ögesi önerilerini karşılama durumunun karşılaştırıması.

\begin{tabular}{|l|c|c|c|c|c|}
\hline & Diyetine uyumlu & Diyetine uyumlu değil & u & z & p \\
\hline Enerji (\%) & 65.5 & 95.3 & 31.0 & -1.2 & 0.20 \\
\hline Protein (\%) & 153.0 & 285.9 & 29.0 & -1.4 & 0.16 \\
\hline Fenilalanin (\%) & 59.6 & 73.2 & 35.0 & -1.0 & 0.30 \\
\hline B $_{\mathbf{6}}$ vitamini (\%) & 299.8 & 587.5 & 25.0 & -1.6 & 0.10 \\
\hline B $_{\mathbf{1 2}}$ vitamini (\%) & 150.0 & 127.5 & 42.5 & -0.5 & 0.56 \\
\hline Folat (\%) & 65.2 & 64.7 & 46.0 & -0.3 & 0.71 \\
\hline C vitamini (\%) & 299.5 & 514.9 & 28.0 & -1.4 & 0.14 \\
\hline Demir (m\%) & 205.8 & 329.8 & 29.0 & -1.4 & 0.16 \\
\hline Kalsiyum (\%) & 162.9 & 285.5 & 23.0 & -1.7 & 0.07 \\
\hline
\end{tabular}

Tablo IV: Çocuğun diyete uyumu ile besin alımını reddetme yöntemi ve annenin besleme davranış özellikleri.

\begin{tabular}{|c|c|c|}
\hline & $\mathbf{n}$ & $\%$ \\
\hline \multicolumn{3}{|l|}{ Çocuğun diyet tedavisine uyumu } \\
\hline Diyet tedavisine uygun olarak her şeyi tüketme & 26 & 86.7 \\
\hline Tabağını bitirmeme/diyet tedavisi dıșında besinler tüketme & 4 & 13.3 \\
\hline \multicolumn{3}{|l|}{ Çocuğun besin alımını reddetme yöntemi } \\
\hline İstemediğini söyleme & 18 & 60.0 \\
\hline Ağızda bekletme & 7 & 23.3 \\
\hline Ağzını açmama & 2 & 6.7 \\
\hline Kafasını çevirme & 2 & 6.7 \\
\hline Eliyle kașı̆ı itme & 1 & 3.3 \\
\hline \multicolumn{3}{|l|}{ Çocuk besin alımını reddettiğinde annelerin davranışı } \\
\hline Beslemekten vazgeçmeme & 24 & 80.0 \\
\hline Bir süre sonra tekrar beslemeye çalıșma & 8 & 26.7 \\
\hline Oyun haline dönüștürme & 7 & 23.3 \\
\hline Televizyon açma & 5 & 16.6 \\
\hline Ödül teklif etme & 2 & 6.7 \\
\hline Zorla yedirme & 2 & 6.7 \\
\hline Beslemekten vazgeçme & 6 & 20.0 \\
\hline
\end{tabular}

üzerinde olduğu belirlenmiştir.

Tablo III'te çocuğun diyete uyumu ile besinlerle fenilalanin alımı, makro-mikro besin öğesi alımlarının önerileri karşılama durumları gösterilmiştir. Çocuğun diyete uyumunun bu parametreleri etkilemediği saptanmıştır ( $p>0.05)$.

Tablo IV'te çocukların büyük çoğunluğunun (\%86.7) diyetine uyumlu olduğu ve besin alımını reddettiğinde doğrudan istemediğini söylediği (\%60.0) gözlenmiştir. Çocuklar besin alımını reddettiğinde annelerin büyük çoğunluğu (\%80.0) çocuklarını beslemekten vazgeçmediği; genellikle annelerin bir süre bekledikten sonra tekrar beslemeye çalıșma (\%26.7) ve oyun haline dönüştürerek çocuğun besin alımını sağladığı (\%23.3) belirlenmiştir.

Tablo V'te çocukların diyet tedavisine uyumları ile anne yaşı, ailedeki çocuk sayısı ve çocuk yaşı arasındaki ilişki ve çocukların z-skor değerleri karşılaştııımıştır. Diyetine uyan çocukların annelerinin ortanca yaşının diyetine uymayan çocukların annelerinden dahayüksekolduğugözlenmiştir $(p=0.03)$. Ailedeki çocuk sayısı ve çocuğun yașı ile çocukların z-skor değerleri ile çocuğun diyete uyumu arasında anlamlı bir fark bulunmamıştır ( $\mathrm{p}$
$>0.05)$. Çocuk besini reddettiğinde annenin besleme davranışı ile çocuğun antropometrik ölçümleri karşılaştırımış ve çocuk besin alımını reddettiğinde beslemeye devam eden annelerin çocuklarının HAZ z-skor değerinin beslemeyi bırakan annelerin çocuklarınkinden daha düşük olduğu bulunmuştur $(p=0.02)$. Çocuk besin alımını reddettiğinde, çocuğu beslemekten vazgeçen annelerin çocuklarının BAZ değerlerinin, beslemekten vazgeçmeyen annelerin çocuklarınkinden daha yüksek olduğu bulunmuştur $(p=0.01)$. Çocuk besin alımını reddettiğinde annenin çocuğu beslemekten vazgeçip vazgeçmemesi ile annenin yaşı, ailedeki çocuk sayısı, çocuğun yaşı arasında anlamlı bir fark bulunmamıştır ( $p>0.05$ ).

Diyete uyumun ve annenin besleme davranışının çocuğun kan fenilalanin düzeyini etkilemediği belirlenmiștir ( $p>0.05$ ).

Çocuk besin alımını reddettiğinde annenin besleme davranışını ile kan fenilalanin düzeyleri, makro ve mikro besin öğesi alımları arasındaki ilişki Tablo Vl'da gösterilmiştir. Annelerin çocuklarını beslemeye yönelik davranışlarının, makro ve mikro besin öğesi alımlarını etkilemediği belirlenmiștir ( $p>0.05)$. 
Tablo V: Çocuğun diyete uyumu ve annelerin çocuklarııı besleme davranışlarının bazı değişkenlerle karşılaştıılması.

\begin{tabular}{|l|c|c|c|c|c|c|}
\hline \multicolumn{1}{|c}{ Değişkenler } & \multicolumn{3}{c}{ Diyete uyum } & \multicolumn{3}{c}{ Anne besleme davranışı } \\
& Uyumlu & Uyumlu değil & p & Beslemeye devam eden & Beslemeyi bırakan & p \\
\hline Anne yaşı (yıl) & 35.0 & 30.0 & $0.03^{*}$ & 34.0 & 36.0 & 0.07 \\
\hline Ailedeki çocuk sayısı & 2.0 & 2.0 & 0.94 & 2.0 & 2.5 & 0.32 \\
\hline Çocuğun yaşı (yıl) & 7.0 & 7.0 & 0.66 & 6.5 & 8.5 & 0.07 \\
\hline Çocuğun WAZ değeri & 0.07 & 0.08 & 0.76 & 0.20 & -0.19 & 0.26 \\
\hline Çocuğun HAZ değeri & -0.35 & 0.12 & 0.42 & -0.48 & 0.80 & 0.02 \\
\hline Çocuğun BAZ değeri & 0.62 & 0.45 & 0.60 & 0.75 & -1.27 & 0.01 \\
\hline
\end{tabular}

${ }^{*} p<0.05$

Tablo VI: Çocuk besini reddettiğinde annenin besleme davranış ile çocuğun kan fenilalanin düzeyi ve makro-mikro besin ögesi alımlarının karşılaştıııması.

\begin{tabular}{|c|c|c|c|c|c|c|c|}
\hline \multirow[b]{2}{*}{ Değişkenler } & \multicolumn{6}{|c|}{ Annenin davranışı (ortanca (sıra ortlaması)) } & \multirow[b]{2}{*}{$\mathbf{p}$} \\
\hline & $\begin{array}{c}\text { Televizyon } \\
\text { eşliğinde } \\
\text { beslenme }\end{array}$ & $\begin{array}{l}\text { Oyun haline } \\
\text { dönüștürme } \\
\text { beslenme }\end{array}$ & $\begin{array}{l}\text { Yemeye } \\
\text { zorlama }\end{array}$ & $\begin{array}{c}\text { Ara vererek } \\
\text { tekrar } \\
\text { beslenme }\end{array}$ & Ödül teklif etme & $\begin{array}{l}\text { Beslemeyi } \\
\text { bırakma }\end{array}$ & \\
\hline $\begin{array}{l}\text { Besinlerle alınan } \\
\text { fenilalanin (mg) }\end{array}$ & $\begin{array}{l}253.7 \\
(11.40)\end{array}$ & $\begin{array}{l}317.7 \\
(13.93)\end{array}$ & $\begin{array}{l}258.0 \\
(14.75)\end{array}$ & $371.8(15.38)$ & $\begin{array}{l}315.4 \\
(18.50)\end{array}$ & $\begin{array}{l}378.8 \\
(20.17)\end{array}$ & 0.663 \\
\hline Enerji (kkal) & $\begin{array}{l}1091.6 \\
(13.40)\end{array}$ & $\begin{array}{l}1208.7 \\
(14.86)\end{array}$ & $\begin{array}{l}1625.5 \\
(19.50)\end{array}$ & $\begin{array}{l}829.2 \\
(12.50)\end{array}$ & $\begin{array}{l}2072.1 \\
(23.00)\end{array}$ & $\begin{array}{l}1296.9 \\
(18.17)\end{array}$ & 0.598 \\
\hline Protein $(g)$ & $\begin{array}{c}58.8 \\
(12.80)\end{array}$ & $\begin{array}{c}46.1 \\
(14.57)\end{array}$ & $\begin{array}{c}81.5 \\
(25.50)\end{array}$ & $\begin{array}{c}55.6 \\
(13.50)\end{array}$ & $\begin{array}{c}86.5 \\
(21.00)\end{array}$ & $\begin{array}{l}56.0 \\
(16.33)\end{array}$ & 0.497 \\
\hline Yağ (g) & $\begin{array}{c}45.4 \\
(14.60)\end{array}$ & $\begin{array}{c}61.6 \\
(14.29)\end{array}$ & $\begin{array}{c}72.7 \\
(12.50)\end{array}$ & $\begin{array}{c}37.4 \\
(11.88)\end{array}$ & $\begin{array}{c}84.3 \\
(24.00)\end{array}$ & $\begin{array}{c}64.5 \\
(20.67)\end{array}$ & 0.336 \\
\hline Karbonhidrat (g) & $\begin{array}{l}153.7 \\
(12.60)\end{array}$ & $\begin{array}{c}162.9 \\
(15.29)\end{array}$ & $\begin{array}{l}157.0 \\
(19.50)\end{array}$ & $\begin{array}{l}139.6 \\
(12.62)\end{array}$ & $\begin{array}{l}239.8 \\
(23.50)\end{array}$ & $\begin{array}{c}166.5 \\
(18.00)\end{array}$ & 0.557 \\
\hline Folik asit (mcg) & $\begin{array}{l}81.1 \\
(9.00)\end{array}$ & $\begin{array}{l}144.2 \\
(15.71)\end{array}$ & $\begin{array}{l}135.8 \\
(18.00)\end{array}$ & $\begin{array}{l}159.0 \\
(18.75)\end{array}$ & $\begin{array}{c}157.2 \\
(16.50)\end{array}$ & $\begin{array}{c}123.0 \\
(15.17)\end{array}$ & 0.547 \\
\hline B6 vitamini (mg) & $\begin{array}{c}2.26 \\
(14.00)\end{array}$ & $\begin{array}{c}1.81 \\
(16.57)\end{array}$ & $\begin{array}{c}2.68 \\
(18.00)\end{array}$ & $\begin{array}{c}0.95 \\
(11,25)\end{array}$ & $\begin{array}{c}3,66 \\
(21.00)\end{array}$ & $\begin{array}{c}2.74 \\
(18.5)\end{array}$ & 0.586 \\
\hline B12 vitamini (mcg) & $\begin{array}{c}1.4 \\
(14.50)\end{array}$ & $\begin{array}{c}1.6 \\
(15.00)\end{array}$ & $\begin{array}{c}1.8 \\
(19.75)\end{array}$ & $\begin{array}{c}2.1 \\
(17.69)\end{array}$ & $\begin{array}{c}1.9 \\
(17.75)\end{array}$ & $\begin{array}{c}1,22 \\
(11.83)\end{array}$ & 0.913 \\
\hline C vitamini (mg) & $\begin{array}{l}184.39 \\
(11.20)\end{array}$ & $\begin{array}{l}190.44 \\
(15.71)\end{array}$ & $\begin{array}{l}272.82 \\
(21.50)\end{array}$ & $\begin{array}{l}217.30 \\
(16.12)\end{array}$ & $\begin{array}{l}281.90 \\
(19.50)\end{array}$ & $\begin{array}{l}191.42 \\
(14.67)\end{array}$ & 0.756 \\
\hline Kalsiyum (mg) & $\begin{array}{l}1515.1 \\
(14.20)\end{array}$ & $\begin{array}{l}1355.2 \\
(17.00)\end{array}$ & $\begin{array}{l}2263.2 \\
(20.00)\end{array}$ & $\begin{array}{l}355.9 \\
(18.18)\end{array}$ & $\begin{array}{l}2806.3 \\
(21.00)\end{array}$ & $\begin{array}{l}1503,3 \\
(17.67)\end{array}$ & 0.523 \\
\hline Demir (mg) & $\begin{array}{c}22.3 \\
(14.60)\end{array}$ & $\begin{array}{c}19.7 \\
(16.57)\end{array}$ & $\begin{array}{c}31.7 \\
(19.00)\end{array}$ & $\begin{array}{c}9.7 \\
(11.75)\end{array}$ & $\begin{array}{c}39.0 \\
(21.50)\end{array}$ & $\begin{array}{c}21.3 \\
(16.83)\end{array}$ & 0.701 \\
\hline
\end{tabular}

\section{TARTIŞMA}

Fenilketonüri tedavisi için yeni yöntemler araştırımakla birlikte temel tedavi yaklaşımı fenilalaninden kısıtlı diyettir. Erken çocukluk döneminde ve reprodüktif çağda diyete uyum sosyal nedenlerle azalmaktadır (10). Türkiye Istatistik Kurumu (TÜiK) Hane Halkı Araştırması sonuçlarına göre 0-5 yaş sağlıklı çocukların \%4.1'i Z skoru değerlerine göre düşük kilolu olarak belirtilmiştir. 2008 ylında yapılan araştırmada ise \%1.7 olarak tespit edilmiştir (20). Acosta ve ark. (2), 2 ile 13 yaş arası beslenme programına uyan PKU'lu çocukların normal lineer büyüme sergilediklerini göstermiştir. Ayrıca, çalışmanın sonunda ortalama BAZ-skorları birçok çocuğun aşırı kilolu olduğunu göstermiştir (21). Fenilketonürili çocuklar diyet için uzun süreli rutin olarak izlense bile, bu popülasyonda fazla kiloluluğun sık görüldüğü belirtilmiştir. $\mathrm{Bu}$ nedenle pediatristlerin ve diyetisyenlerin, PKU hastalarında enerji alımı, fiziksel aktivite ve ağırlık yönetimini dikkatle takip etmeleri gerektiği belirtilmektedir (22). Bu çalş̧mada ise benzer olarak BAZ-skorlarına göre obezitenin zayıflığa kıyasla daha yaygın ve çocukların \%40.0'nın obez, \%6.7'sinin ise zayıf olduğu belirlenmiştir. 
Japonya'da 2016 yllında yapılan bir çalışmada PKU'lu 10 çocuğun enerji ve besin öğesi alımları önerilen yeterli alım düzeyi (RDA) ile karşılaştııımış ve çocukların enerji intiyaçlarının ortalama \%100.6 \pm 18.4 oranında karşılandığı tespit edilmiştir (23). Bu çalışmada yaşa göre enerji gereksiniminin diyet tedavisiyle karşılanma yüzdesinin ortalama $77.7 \pm 34.1$ olduğu görülmüştür. Bu durumun sosyo-kültürel farkllıklara bağlı olarak ailelerin ve çocukların yeme davranışı, diyete uyum oranları ve ailelerin disiplin anlayışındaki farkllıktan kaynaklanabileceği düşünülmüştür.

Fenilketonürili çocuklar için oluşturulan diyet programını sürekli olarak uygulamak ve denetlemek ebeveynlik becerisine ve disiplinine bağlıdır. Çocuğun uyumu; ebeveynlerin düşük fenilalanin içeren diyeti sağlama durumundan, uygulamadaki becerilerinden, ailenin sosyal desteğinden, ailedeki bireylerin hastallk ve diyetle baş etme becerilerinden etkilenmektedir (24). Ustuner Top ve Alemdar. (17), PKU'lu çocuklar ve aileleriyle yaptığı çalışmada, çocukların özel beslenme ürünlerini temin etmede ailelerin ekonomik güçlük yaşadıkları belirtilmiştir. Ayrıca normal kan fenilalanin düzeyinde diyeti esnetmeleri, çocukların özel beslenme ürünlerinden sıkımaları nedeniyle yaptıkları kaçamaklar, ailelerin okulda çocuklarını kontrol etmekte zorlanmaları, eșler arasında çocuğun bakımı konusunda gerginlik yaşanması gibi sebeplere bağlı olarak diyete uyumda hem ailelerin hem de çocukların çeșitli güçlüklerle karșılaștıkları gözlenmiștir (17). Bu çalışmada ise çocukların büyük çoğunluğunun (\%86.7) diyetine uyumlu olduğu gözlenmiştir. Çocukların çoğunluğunun bir besini tüketmek istemediğinde bunu sözel olarak belirttiği saptanmıştır (\%60). İki-üç yaş grubunda çocukların ağzını açmayarak ve kafasını çevirerek besini tüketmek istemediğini belirtirken, 4-6 yaș grubunda çocukların istemediğini söylediği ve ağzında beklettiği belirlenmiştir. Yedi-10 yaş grubundaki çocuklar çoğunlukla istemediklerini söylerken, ağzında bekletmenin de yaygın olduğu, 11-14 yaşında ise istemediklerini söyledikleri görülmüștür.

Beslenme kontrolünün yetersiz olması genellikle daha büyük çocukların diyete uyumunun azalması ile ilişkili olduğu, aynı zamanda ebeveynler tarafindan daha rahat bir diyet yaklașımının sağlanması ve diyetle ilişkili hataların artmasından da kaynaklanabilmektedir (24). Çocuklar besin alımını reddettiğinde anneler genelde (\%80) çocuklarını beslemekten vazgeçmemekte, bir süre bekledikten sonra tekrar beslemeye çalışma (\%26.7) ile oyun haline dönüştürerek (\%23.3) çocuğun besin alımını sağlamaya çalıștığı görülmüștür. Tanımlayıcı tipte yapılan bu çalışmada çocuğun yaşına göre değerlendirildiğinde, sadece 7-10 grubunda çocukları olan anneler beslemeyi bırakmakta iken $(n=6)$, diğer yaş grubundaki anneler beslemeye devam etmek için çaba sarf ettiklerini belirtmiștir. İki-üç yaș grubunda anneler daha çok televizyon eşliğinde beslenmeyi tercih ederken, 4-6 yaș grubunda anneler oyun haline getirme ve bir süre bekledikten sonra tekrar beslemeyi tercih etmiştir. Yedi-10 yaş grubunda çocukları olan anneler bir süre bekledikten sonra tekrar beslemeyi, zorla yedirmeyi ve ödül teklif ettiği belirlenmiștir. 11-14 yaș grubunda çocukları olan anneler ise oyun haline getirmeyi ve bir süre bekledikten sonra tekrar beslemeyi tercih etmiştir. Yaş grubuna göre değerlendirdiğimizde annelerin farklı yaklaşımlara sahip oldukları görülmüştür. Annenin beslenme davranışının çocuğun enerji, makro ve bazı mikro besin ögesi alımlarına anlamlı bir etkisi olmadığı gözlenmiștir. Bu durumun örneklem boyutunun küçük olmasından kaynaklandığı düşünülmüştür.

Hane geliri, ebeveyn yaşı ve aile büyüklüğü gibi demografik faktörlerin genel kontrol (çocuğun diyeti, kan fenilalanin düzeyleri, vb) üzerine etkisi olmadığı tespit edilmiştir (24). Bu çalışmada çocukların diyete uyumları ile annelerin yașının ilișkili olduğu, diyetine uyumlu çocukların annelerinin yaşının daha büyük olduğu gözlenmiştir. Bu durum hassas takip ve izlem gerektiren PKU'lu çocukların beslenmesinde anne yaşının, artan tecrübeyle ilişkili olumlu sonuçlara yol açabileceğini düşündürmektedir.

Çocuğun diyete uyumu ile WAZ, HAZ ve BAZ skoru arasında anlamlı farklar gözlenmemiştir. Besin reddine karşı annenin beslenme davranışının çocuğun antropometrik ölçümlerini etkilediği saptanmıștır. Buna göre çocuk besin alımını reddettiğinde çocuklarını beslemekten vazgeçmeyen annelerin çocuklarının HAZ değeri daha düşük iken, BAZ değerinin daha yüksek olduğu bulunmuştur.

Örneklem sayısının küçük olması, besin tüketim kaydının geriye dönük 24 saatlik besin tüketim kaydına dayanması bu çalıșmanın sınırlılıklarını oluşturmaktadır. Besin tüketimlerini tespit etmeye yönelik, ailelerden birden fazla günü içeren tüketim kayıtlarının alınması verilerin güvenilirliğini arttırabilir. Fenilketonürili çocuklar ve aileleri ile yüz yüze görüșme sağlanmıș olup, çalıșmanın planlama așamasında ailelerin üye oldukları dernek ile iș birliği içerisinde çalışılmış olması hastalı̆ı̆ beslenme ile ilişkisine dair gözden kaçabilecek noktaların tespit edilmesi açısından faydalı olmuştur.

Sonuç olarak; çocukların diyete uyumunu ailenin ve çocuğun bakımından sorumlu kișinin etkilediği görülmüștür. Fenilketonürili çocukların besin alımını reddetme tutumlarını ve diyette olmayan bir besinle karșılașıldığında istedikleri halde yemekten kaçınmalarının, tanıdan itibaren diyet uyumu geliştirmeleriyle ilişkili olduğu düşünülmüştür. Çocukların diyete uyumunu zorlaştıran etmenlerin ve bu etmenleri etkileyen çevresel faktörlerin de araștırıması önemlidir. Farklı eğitim yöntemleri ile çeşitli yaklaşımlar geliştirilmeli ve ebeveynler ile çocukların bilgi ișlem kapasitesindeki bireysel farklılıkları dikkate alınarak eğitim programları düzenlenmelidir. Ayrıca örneklem boyutu artırıarak beslenme davranışlarının detaylı incelenmesi sağlanmalıdır. 


\section{KAYNAKLAR}

1. Türkiye İstatistik Kurumu Aile Yapısı Araştırması (TÜiK). Erişim tarihi: 16 Eylül 2019. E erişim https://ailevecalisma.gov.tr

2. Tokatı A. Doğuştan metabolik hastalıklara tanısal yaklaşım. Güncel Pediatri 2006; 4:133-8.

3. Tolunay I, Yıldızdaş RD, Horoz ÖÖ, Petmezci E, Ekinci F, Mungan N. Doğuştan metabolik hastalıkların tedavisinde ekstrakorporeal yöntemler. Arşiv Kaynak Tarama Dergisi 2015;4:509-19.

4. Köksal G, Özel Gökmen H. Çocuk Hastalıklarında Beslenme Tedavisi, Doğuştan Metabolizma Hastalıkları. 1. Baskı. Ankara: Hatiboğlu Basım ve Yayım San, Tic, Ltd, Şti, 2015:359-547.

5. Blau N, Spronsen FJ, Levy HL. Phenylketonuria. Lancet 2010;376:1417-27.

6. Ahring K, Be'langer-Quintana A, Dokoupil K. Dietary management practices in phenylketonuria across European centres. Clin Nutr 2009;28:231-6.

7. Loeber JG. Neonatal screening in Europe; the situation in 2004. J Inherit Metab Dis 2007;30:430-8.

8. Özbaş S. Türkiye'de yenidoğan tarama programı. Uluslararası Katıımlı IX. Metabolik Hastalıklar ve Beslenme Kongre Kitabı. Uluslararası Katıımlı IX. Metabolik Hastalıklar ve Beslenme Kongresi; 2011; Izmir, Türkiye; 2011. p. 4.

9. Büyükgebiz B, Öztürk Y. Doğumsal metabolik hastalıklarda beslenme. Klin Cocuk Forum 2002;2:38-44.

10. Erol S, Işık DU, Çelik IH, Baş AY, Demirel N. Maternal fenilketonüri sendromuna bağlı çoklu konjenital anomali gelişen iki olgu. Türkiye Çocuk Hast Derg 2016;11:286-8.

11. Al Hafid N, Christodoulou J. Phenylketonuria: a review of current and future treatments. Transl Pediatr 2015;4:304-17.

12. Çevik $A$, Ertaş N. Fenilketonüri hastalığı ve hastalığa uygun gıda üretimi. Bozok Tıp Dergisi 2019;10:256-63.

13. Köksal G, Özel Gökmen H. Metabolik hastalıklarda beslenme 1st ed. Ankara: Sağlık bakanlığı yayınları, 2012:1-37. E erişim: https:// sbu.saglik.gov.tr/Ekutuphane/kitaplar/t56.pdf
14. 14. Çoker M. Metabolik hastalıklarda beslenme. İçinde: Selimoğlu MA (edt) Sağlıkta ve Hastalıkta Çocuk Beslenmesi. 1. Baskı. İstanbul: Akademi Yayınevi, 2014:403-416.

15. Crone MR, Van Spronsen FJ, Oudshoorn K, Bekhof J, Van Rjin $\mathrm{G}$, Verkerk $\mathrm{PH}$. Behavioural factors related to metabolic control in patients with phenylketonuria. J Inherit Metab Dis 2005;28:627-37.

16. Evans S, Daly A, Chahal S, MacDonald J, MacDonald A. Food acceptance and neophobia in children with phenylketonuria: a prospective controlled study. J Hum Nutr Diet 2016;29: 427-33.

17. Top FÜ, Alemdar DK. Fenilketonürili çocuğu olan ailelerinin yaşadıkları güçlükler: Niteliksel bir çalışma. Hemşirelikte Eğitim ve Araştırma Dergisi 2015; 12: 62-8.

18. Besler HT, Rakıcıoğlu N, Ayaz A, Büyüktuncer Demirel Z, Gökmen Özel H, Samur F ve ark. Türkiye'ye özgü besin ve beslenme rehberi. Ankara: Merdiven Reklam Tanıım, 2015:96.

19. World Health Organization WHO AnthroPlus for personal computers Manual: Software for assessing growth of the world's children and adolescents. Erișim tarihi: 16 Eylül 2019. Available from: https:// www.who.int/

20. Türkiye İstatistik Kurumu (TÜiK) Sağlık Araștırması (Health Survey) 2010. Erişim tarihi: 16 Eylül 2019. E erişim: http://www.tuik. gov.tr/

21. Acosta PB, Yannicelli S, Singh R, Mofidi S, Steiner R, DeVincentis $\mathrm{E}$, ve ark. Nutrient intakes and physical growth of children with phenylketonuria undergoing nutrition therapy. J Am Diet Assoc 2003;103:1167-73.

22. Giovannini M, Verduci E, Salvatici E, Fiori L. Phenilketonuria: Dietary and therapeutic challenges. J Inherit Metab Dis 2007;30:145-52.

23. Okano Y, Hattori T, Fujimoto H, Noi K, Okamoto M, Watanabe T, ve ark. Nutritional status of patients with phenylketonuria in Japan. Mol Genet Metab Rep 2016;8:103-10.

24. MacDonald A, Davies P, Daly A, Hopkins V, Hall SK, Asplin D, ve ark. Does maternal knowledge and parent education affect blood phenylalanine control in phenylketonuria? J Hum Nutr Diet 2008;21:351-8. 